\title{
Biochemical Basis of Calpain and Calpastatin Activity \\ Determination in Blood and Tissue Samples: Potential Role in \\ Post-Mortem Ageing of Guinea Fowl Meat
}

\author{
Biswas $\mathrm{AK}^{*}$ and Tandon $\mathrm{S}$ \\ Division of Post-Harvest Technology, ICAR-Central Avian Research Institute, IVRI campus, \\ Izatnagar, Bareilly-243 122 (U.P.), India
}

*Corresponding author: Biswas AK, Division of Post-Harvest Technology, ICAR-Central Avian Research Institute, IVRI campus, Izatnagar, Bareilly-243 122 (U.P.), India, Tel: +91-581-2303223; Email: biswaslpt@gmail.com

\section{Research Article \\ Volume 3 Issue 2}

Received Date: March 14, 2018

Published Date: May 07, 2018

\section{Abstract}

Calpains, the calcium-dependent thiol-proteases have been implicated in various important cellular processes including tenderization of meat. So, aim of this study was to identify calpains and their potential inhibitor calpastatin in blood and skeletal muscles to elucidate their role in post-mortem tenderization of guinea fowl meat during holding at $4 \pm 1{ }^{\circ} \mathrm{C}$. For this, breast and thigh muscles of two different guinea fowl varieties were collected, processed, and finally, analyzed on casein Zymogram gels. The sample extracts were also subjected to dialysis (12 kDa MWCO) and loaded on DEAE anion column for purification and separation of $\mu$ - and m-calpains as well as calpastatin. Results show that there were clear bands of $\mu$ - and m-calpains in the extracts of both the blood and muscle samples. But the band intensity for muscle samples kept decreasing with the increase of holding time showing the decreasing trend in activity of these enzymes. The calpastatin activity was also decreased rapidly and greatly. The $\mathrm{pH}$ and $\mathrm{W}$-B shear force values were decreased with the increase in holding time. Finally, the $\mu$-calpain induced post-mortem maturation time was optimized at $6 \mathrm{~h}$ for breast and thigh muscles of both the varieties of guinea fowl.

Keywords: Calpains; Zymography; Ageing; Guinea Fowl Meat; Chromatography

\section{Introduction}

Guinea fowl (Numida meleagris) meat is a nutritionally desirable alternative to consumers than meat from other livestock and poultry species [1]. During the past few years much of the poultry consuming countries have switched to this bird to produce meat for luxury markets, and there is still a vast, untapped future for its meat [2]. Guinea fowl meat is preferred on account of its dark gamey taste, colour and higher mineral composition but 


\section{Food Science and Nutrition Technology}

in low in fat content than other poultry species. The meat from this species could be an excellent and healthy alternative to the consumers, but only little research exploitation has been done for improvement its quality, in particularly tenderness. In comparison to broiler meat and also other chicken varieties, meat from guinea fowl is tougher even at its slaughter weight at 12 weeks of age. It has been well documented that post-mortem acidification/proteolysis of meat has greater role in improvement of tenderness $[2,3,4,5,6]$ but this phenomenon of post-mortem acidification is also poorly documented for this species [7]. Earlier studies demonstrated that calpain system comprising of calciumdependent endogenous proteases $\mu$-calpain, m-calpain and their inhibitory enzyme calpastatin have a major role in post-mortem skeletal muscle breakdown which results in tenderness of meat [8]. Moreover, the role of these enzymes in blood still requires meticulous studies, due to variation in the two biological matrices.

Although the process of meat tenderization during post-mortem holding of carcasses is a well-known practice, the mechanism through which these changes are brought remains elusive and controversial.

However, the calpain theory of tenderization was recognized as the most probable theory for post-mortem changes of muscles [9]. Under this theory it is also well documented that $\mu$-calpain and calpastatin progressively lost their activity during post-mortem maturation, but mcalpain remained stable. So, to better understand the role of calpain system in meat tenderness, this study contemplates to identify the activity of $\mu$ - and m-calpains and calpastatin in blood and tissue samples from two different varieties, and also to understand their possible role in post-mortem tenderization of breast and thigh muscle during holding at $4 \pm 1{ }^{\circ} \mathrm{C}$. The changes in muscle $\mathrm{pH}, \mathrm{W}$-B shear force value were also monitored to optimize $\mu$-calpain induced post-mortem maturation of guinea fowl meat from two different varieties.

\section{Materials and methods}

\section{Chemicals and Reagents}

Casein from bovine milk (purified powder); dialysis tubing cellulose membrane (12 kDa-MWCO), DEAESephacel (anion exchanger), protease inhibitors (leupeptin hemisulfate, ovomucoid) were procured from Sigma-Aldrich, USA. Another protease inhibitor phenylmethane sulfonylfluoride (PMSF) was obtained from Sisco Research Laboratories, Mumbai, India.
Novagen perfect protein marker $(10-225 \mathrm{kDa})$ was obtained from Merck Millipore, Mumbai, India. An EconoColumn $(1.5 \times 8.5 \mathrm{~cm})$ used for chromatography analysis was procured from Bio-Rad Laboratories, Lucknow, India. All other solvents and reagents required for this experiment were of standard grade and procured from s. D. Fine Chemicals, New Delhi, Sisco Research Laboratories, Mumbai and Merck Specialist Pvt. Ltd., Mumbai, India.

\section{Raw Material Collection}

A total of 80 muscle samples (comprising 40 breast and thigh muscles) from 80 culled (52 wk age) guinea fowl birds (40 Pearl and 40 Swetambari) were collected from Experimental Poultry Processing Plant of ICAR-Central Avian Research Institute, India. The birds were slaughtered as per standard slaughtering practices. Immediately after exsanguination, the skin covering muscles was opened and the breast and thigh muscles were collected. The samples were collected from grading table where tissue samples were excised, packed and chilled immediately. About $300 \mathrm{~g}$ of muscle samples were collected and transferred in to a self-sealing LDPE bags. The bags were labeled and transported to laboratory under chilled condition for analysis. Blood samples (15 $\mathrm{mL}$ from each bird) were collected from the birds during bleeding operations where they were hung, stunned and slaughtered manually. The blood samples were collected in the vials containing EDTA $(1 \mathrm{mg} / \mathrm{mL}$ blood $)$ and transferred to the laboratory for processing immediately.

\section{Processing and extraction of samples}

For processing of samples, excessive connective tissues, fat and fascia were trimmed-off and each muscle sample was sub-divided into three individual groups. All samples were held at $4 \pm 1{ }^{\circ} \mathrm{C}$ for evaluation of biochemical changes at 0,6 and $24 \mathrm{~h}$ of post-mortem maturation. Accurately 3 $\mathrm{g}$ of these finely cut sample was weighed and homogenized using pestle and mortar- in pre-chilled conditions with 6 volumes of ice-cooled extraction buffer comprising of tris-base $50 \mathrm{mM}(\mathrm{w} / \mathrm{v})(\mathrm{pH} 8.3), 10 \mathrm{mM}$ EDTA (w/v) and $0.05 \%$ (v/v) 2-mercaptoethanol (MCE). Protease inhibitors [2 mM (PMSF), $100 \mathrm{mg} / \mathrm{L}$ ovomucoid and $6 \mathrm{mg} / \mathrm{L}$ leupeptin] were incorporated in the extraction buffer just before use to avoid the functioning of unwanted enzymes. The extract was then subjected to centrifugation (Make-Eppendorf 5427R, Germany) at $12000 \mathrm{rpm}$ for $20 \mathrm{~min}$ at $4{ }^{\circ} \mathrm{C}$. Supernatant was decanted in a separate centrifuge tube and sediment was disposedoff. The collected supernatant was centrifuged once again as mentioned earlier and was later filtered and collected 


\section{Food Science and Nutrition Technology}

in a separate centrifuge tube [10]. Both breast and thigh samples from all the birds were processed similar manner at different time of PM ageing. Likewise, for blood, samples $(1.15 \mathrm{~mL})$ were homogenized with 3 volumes of extraction buffer (as prepared previously), but additionally $0.1 \%$ Triton X-100 (v/v) was included while making blood extracts. Other processing steps remained same as mentioned above for meat extract preparation.

\section{Purification and Separation}

Purification and separation steps are mandatory for proper identification of calpains and calpastatin. In order to achieve this, supernatant as obtained was first kept in a dialysis buffer ( $\mathrm{pH} 7.4$ ) comprising $40 \mathrm{mM}$ tris-base, $5 \mathrm{mM}$ EDTA and $0.05 \%(\mathrm{v} / \mathrm{v})$ MCE. The ratio of buffer and sample extract was maintained at 20:1 or more. Dialysis was performed overnight at $4^{\circ} \mathrm{C}$ using dialysis tubing of $12 \mathrm{kDa}$ MWCO cellulose filter (Sigma-Aldrich, USA). Fresh dialysis buffer was prepared for each sample and that was stored at $4 \pm 1{ }^{\circ} \mathrm{C}$ until use.

For purification and separation of $\mu$-calpain, m-calpain and calpastatin, anion exchange chromatography was performed in which supernatant obtained after dialysis was loaded on a pre-conditioned Econo-Column (W×L; 1.5 x $8.5 \mathrm{~cm}$ ) supplied by Bio-Rad Laboratories, Lucknow, India. Swollen DEAE-Sephacel (Sigma-Aldrich, USA) was used as column matrix. The column was equilibrated through three washings $(3 \times 20 \mathrm{~mL})$ with equilibration buffer (pH 7.4) containing $40 \mathrm{mM}$ tris-base, $0.5 \mathrm{mM}$ EDTA and $0.05 \%$ MCE. Sample extract corresponding to $3 \mathrm{~g}$ of meat or $1.15 \mathrm{~mL}$ of blood sample was loaded on a column having $5 \mathrm{~cm}$ settled DEAE-Sephacel. The calpains and calpastatin were eluted using gradient elution method with increasing concentrations of $\mathrm{NaCl}$ solution. Calpastatin were eluted first at $100 \mathrm{mM} \mathrm{NaCl}$ followed by $\mu$ - and m-calpain at $200 \mathrm{mM}$ and $400 \mathrm{mM} \mathrm{NaCl}$ concentrations, respectively [11].

\section{Analysis}

\section{Casein Zymography}

Casein zymography method was performed for the detection of calpains as per methodology of Huang [4] with suitable modification. In modified method, the casein gels were pre-run on Mini-PROTEAN tetra system (BioRad Laboratories, USA) at $100 \mathrm{~V}$ for $15 \mathrm{~min}$ at $4{ }^{\circ} \mathrm{C}$ with running buffer ( $\mathrm{pH}$ 8.3). Sample was prepared by mixing the crude extract with sample buffer $(3: 1, v / v)$, and was then loaded on the casein gel and subjected to electrophoresis at $100 \mathrm{~V}$ for $4 \mathrm{~h}$ at $4{ }^{\circ} \mathrm{C}$. After completion of electrophoresis, the gels were incubated for 18-24 hrs at $20^{\circ} \mathrm{C}$ in proteolytic buffer (pH 7.4) comprising $20 \mathrm{mM}$ tris-base, $10 \mathrm{mM}$ Ditheothreitol (DTT) at $\mathrm{CaCl} 2$ concentration of $4 \mathrm{mM}$. The gel was then stained for 60 min with Coomassie Brilliant Blue G-250 and then kept overnight in de-staining solution which gives clear bands of calpains [12]. The presence of calpains was clearly identified due to the digestion of casein molecules into small fragments that diffuse out of the gel.

\section{SDS-PAGE Analysis}

As calpastatin along with its different domains lacks the proteolytic activity, casein zymography cannot be used for its detection. Considering this, SDS-PAGE analysis was performed for identification of calpains and calpastatin from the purified fractions obtained after anion exchange chromatography [11]. In this method, resolving gel was polymerized with $0.05 \%(\mathrm{w} / \mathrm{v})$ APS and $0.05 \%(\mathrm{v} / \mathrm{v})$ TEMED while the stacking gel containing was polymerised with $0.05 \%$ APS and $0.1 \%$ TEMED. The purified fractions were diluted with sample buffer $(1: 2, v / v)$ and then heated at $95^{\circ} \mathrm{C}$ for 5 minutes. The samples were loaded in the gel and electrophoresis was performed at constant voltage of $120 \mathrm{~V}$ for 90 min with the electrode running buffer. On completion of electrophoresis the gel was stained for $1 \mathrm{~h}$ in the solution containing $0.1 \%(\mathrm{w} / \mathrm{v})$ Coomassie Brilliant Blue G-250, 40 \% (v/v) methanol and $10 \%(\mathrm{v} / \mathrm{v})$ acetic acid and was destained in a solution comprising $30 \%(\mathrm{v} / \mathrm{v})$ methanol and $10 \%(\mathrm{v} / \mathrm{v})$ acetic acid [13].

\section{Determination of calpains and calpastatin activity}

Calpain activity was determined based on the extent of proteolysis of calpains and by measuring the amount of peptides released from casein by calcium dependent proteases. The calpastatin activity was measured by incubating appropriate amounts of pooled fractions containing calpastatin and $\mathrm{m}$-calpain at $4^{\circ} \mathrm{C}$ for $1 \mathrm{~min}$ before adding $1.5 \mathrm{~mL}$ assay buffer containing $\mathrm{CaCl} 2$ to start the reaction. The reaction was stopped by adding 5 $\%$ TCA and centrifuged as mentioned earlier. Three tubes were used to assay inhibitor activity: (1) m-calpain pooled fraction, incubated with assay buffer containing $\mathrm{CaCl} 2$; (2) m-calpain fraction plus calpastatin fraction, incubated in assay buffer as described in 1; (3) calpastatin fraction alone, incubated in assay buffer containing EDTA. Total inhibitor activity was calculated according to the formula: Total inhibitor activity (Units/g) $=1-(2-3) \times$ dilution factors $[14,15]$. 


\section{Food Science and Nutrition Technology}

\section{Determination pH}

The $\mathrm{pH}$ of muscles was determined at various time intervals $(0,6,24 \mathrm{hrs})$ as per the standard method to study its influence on calpains and calpastatin activity during post-mortem maturation at $4 \pm 1{ }^{\circ} \mathrm{C}$ [16]. The $\mathrm{pH}$ value was measured with a Bench top digital $\mathrm{pH}$ meter (Eutech 2700) equipped with glass electrode and automatic temperature sensors on $10 \mathrm{~g}$ of sample homogenized with $50 \mathrm{~mL}$ of distilled water using pestle and mortar for $2 \mathrm{~min}$. The $\mathrm{pH}$ values were correlated with changes in activity of $\mu$ - and $\mathrm{m}$-calpains and calpastatin.

Determination W-B shear force value: Warner-Bratzler shear blade attached to TA-HDi Texture Analyser (Stable Micro System, UK) equipped with $50 \mathrm{~kg}$ load cell was used to evaluate the effect of maturation on tenderness and correlate the results with zymography and SDS-PAGE analysis. Test speed was $4 \mathrm{~mm} / \mathrm{s}$ and travel distance was $25 \mathrm{~mm}$. Maximum force required to cut raw strips $(3 \mathrm{~cm}$ $\times 1 \mathrm{~cm} \times 1 \mathrm{~cm} ; \mathrm{L} \times \mathrm{W} \times \mathrm{H}$ ) was measured as $\mathrm{Kg} / \mathrm{cm} 2$.

\section{Statistical analysis}

Experimental data generated were analyzed statistically using standard software package [17]. Means of calpains and calpastatin activity and other data of physicochemical analysis relating to post-mortem maturation were evaluated using two-way ANOVA.
Homogeneity test and DMRT were used for comparing means to find the effects between post-mortem times and their interactions were performed. The statistical significance was expressed at $\mathrm{P}<0.05$.

\section{Results and discussion}

\section{Casein zymography}

Casein zymography method is based on the principle that casein molecules present in the gel are catalyzed by calpains in the presence of $\mathrm{Ca}^{2+}$ ion in solution. Both blood and muscle sample extracts showed ample proteolytic activity of calpains on zymography gel. However, the proteolytic activity of extracts obtained from muscle samples showed the decreasing trends with the increase in post-mortem maturation at $4 \pm 1{ }^{\circ} \mathrm{C}$. Among the two varieties the band intensity for Swetambari was greater than that identified for Pearl. Similar results were obtained for blood samples. It has also been found that the bands obtained from breast muscle samples showed greater intensity then the bands obtained from thigh muscles in both the varieties (Figure 1B) and (Table 1). Bands of $\mu$-calpain from breast muscle were clearly visible only up to $6 \mathrm{~h}$ for both the varieties, but bands for thigh muscle were visible only at initial period, and were autolyzed at $6 \mathrm{~h}$ (Figure $1 \mathrm{C} \& \mathrm{D}$ ). In the case of m-calpain the proteolytic activity was completely stable even upto $24 \mathrm{~h}$ (Figure 1a).

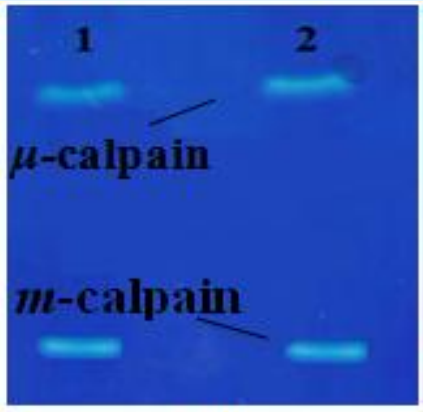

(A)

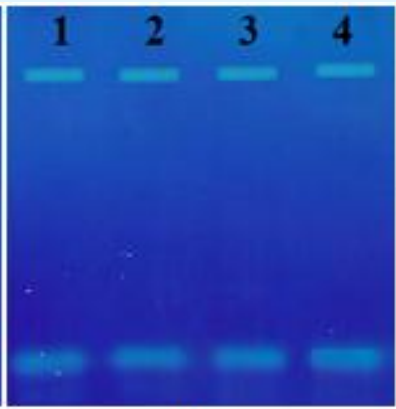

(B)

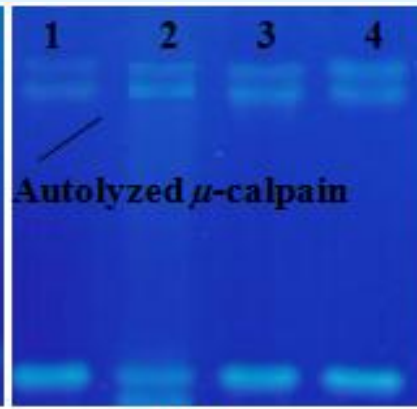

(C)

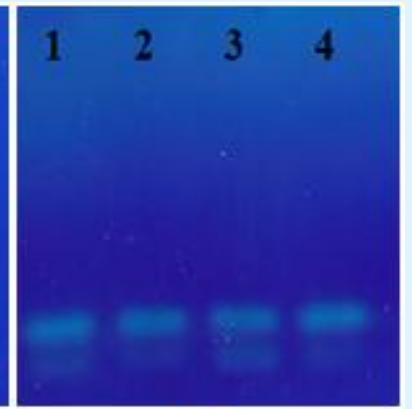

(D)

Figure 1: $\mu$ - and $m$-calpains on casein gel

(A) Lane-1: Swetambari Blood; Lane-2: Pearl Blood.

(B) 0 h: Lane-1: Swetambari Breast; Lane-2: Swetambari Thigh; Lane-3: Pearl Breast; Lane-4: Pearl Thigh.

(C) 6 h: Lane-1: Swetambari Breast; Lane-2: Swetambari Thigh; Lane-3: Pearl Breast; Lane-4: Pearl Thigh.

(D) 24 h: Lane-1: Swetambari Breast; Lane-2: Swetambari Thigh; Lane-3: Pearl Breast; Lane-4: Pearl Thigh. 


\section{Food Science and Nutrition Technology}

\begin{tabular}{|c|c|c|c|c|}
\hline \multirow{2}{*}{ Guneafowl } & \multirow{2}{*}{ Muscle Type } & \multicolumn{3}{|c|}{ Post-mortem aging time } \\
\hline & & $\mathbf{0 ~ h}$ & $6 \mathrm{~h}$ & $24 \mathrm{~h}$ \\
\hline \multicolumn{5}{|c|}{$\mu$-calpain } \\
\hline \multirow{2}{*}{ Swetambari } & Breast & $0.47 \pm 0.05^{\mathrm{cD}}$ & $0.21 \pm 0.02^{\mathrm{bD}}$ & $0.08 \pm 0.04^{\mathrm{aD}}$ \\
\hline & Thigh & $0.29 \pm 0.03^{\mathrm{cB}}$ & $0.13 \pm 0.01^{\mathrm{bB}}$ & $0.06 \pm 0.05^{\mathrm{aB}}$ \\
\hline \multirow{2}{*}{ Pearl } & Breast & $0.36 \pm 0.04 \mathrm{cC}$ & $0.19 \pm 0.03^{\mathrm{bc}}$ & $0.07 \pm 0.01^{\mathrm{ac}}$ \\
\hline & Thigh & $0.25 \pm 0.02^{\mathrm{cA}}$ & $0.09 \pm 0.04^{\mathrm{bA}}$ & $0.05 \pm 0.03^{\mathrm{aA}}$ \\
\hline \multicolumn{5}{|c|}{ m-calpain } \\
\hline \multirow{2}{*}{ Swetambari } & Breast & $2.01 \pm 0.06^{\mathrm{aA}}$ & $1.96 \pm 0.02^{\mathrm{aA}}$ & $1.93 \pm 0.04^{\mathrm{aA}}$ \\
\hline & Thigh & $1.98 \pm 0.05^{\mathrm{aA}}$ & $1.88 \pm 0.03^{\mathrm{aA}}$ & $1.85 \pm 0.01^{\mathrm{aA}}$ \\
\hline \multirow{2}{*}{ Pearl } & Breast & $1.97 \pm 0.02^{\mathrm{aA}}$ & $1.99 \pm 0.06^{\mathrm{aA}}$ & $1.91 \pm 0.05^{\mathrm{aA}}$ \\
\hline & Thigh & $1.89 \pm 0.04^{\mathrm{aA}}$ & $1.84 \pm 0.03^{\mathrm{aA}}$ & $1.81 \pm 0.02^{\mathrm{aA}}$ \\
\hline \multicolumn{5}{|c|}{ Calpastatin } \\
\hline \multirow{2}{*}{ Swetambari } & Breast & $1.09 \pm 0.01^{\mathrm{bD}}$ & $0.89 \pm 0.04 \mathrm{aD}$ & $0.71 \pm 0.03^{\mathrm{aD}}$ \\
\hline & Thigh & $0.92 \pm 0.02^{\text {св }}$ & $0.79 \pm 0.03^{\mathrm{bB}}$ & $0.62 \pm 0.01^{\mathrm{aB}}$ \\
\hline \multirow{2}{*}{ Pearl } & Breast & $0.99 \pm 0.04^{\mathrm{cC}}$ & $0.72 \pm 0.02^{\mathrm{bC}}$ & $0.53 \pm 0.03^{\mathrm{ac}}$ \\
\hline & Thigh & $0.81 \pm 0.03^{\mathrm{cA}}$ & $0.69 \pm 0.05^{\mathrm{bA}}$ & $0.47 \pm 0.04^{\mathrm{aA}}$ \\
\hline
\end{tabular}

Table 1: Changes in Calpains and Calpastatin Activity* During Post-Mortem Maturation at $4 \pm 1{ }^{\circ} \mathrm{C}$

$\mathrm{n}=20$; Mean \pm S.E with different superscript row-wise (small letter) and column-wise (capital letter) differ significantly $(\mathrm{P}<0.05)$.

*Unit: Units/g

Similar results were reported for chicken Pectoralis muscle at different time intervals [7] and complete absence of $\mu$-calpain was found at $24 \mathrm{~h}$ post-mortem maturation. However, the studies conducted for lamb Longissimus dorsi muscle showed absence of $\mu$-calpain at $72 \mathrm{~h}$ post-mortem [18], while m-calpain remained stable in both the studies. These studies hence conclude that $\mu$ calpain present in guinea fowl species are less stable and shows rapid proteolytic activity, explaining the fact why avian muscles tenderize rapidly than there mammalian counterparts.

\section{Identification of Calpains and Calpastatin in SDS-PAGE Analysis}

SDS-PAGE analysis was mainly conducted to determine the presence of calpastatin in the crude extracts. Result depicted in Figure 2 indicates that the fractions eluted with $200 \mathrm{mM}$ and $400 \mathrm{mM} \mathrm{NaCl}$ showed similar pattern of prominent bands for breast and thigh muscle samples from Swetambari and Pearl varieties.

There was a clear presence of prominent bands at molecular weight of 78, 76, 75 and $66 \mathrm{kDa}$ for catalytic subunits and 30, 28 and $25 \mathrm{kDa}$ for regulatory subunits in both muscle and blood samples indicating native and autolyzed forms of $\mu$ - and m-calpains. The $100 \mathrm{mM}$ eluted fraction of blood samples showed completely different band patterns to that of 200 and $400 \mathrm{mM} \mathrm{NaCl}$ fractions. In both the varieties prominent bands were identified at molecular weight of 78, 66, 30, 28 and 25kDa for blood samples. However for breast and thigh muscle samples the bands were visualized at $100,78,66,50,40,30,28$, and $25 \mathrm{kDa}$. The elution pattern obtained for $100 \mathrm{mM}$ fraction showed contradictory result to the earlier findings in lamb and beef muscles [6, 18, 19]. This variation of band pattern could be due to the fact that calpastatin contains 4 repeating, marginally homogenous domains I, II, III and IV, and in addition to N-terminal domain, the L-domain that varies in size due to alternative splicing events and different strategies of transcription, although it (L-domain) has no inhibitory activity.

During maturation process (Figure 2), similar band pattern as mentioned above was observed but intensity of band clearance decreased with increase of maturation time and there was minor presence of bands at $24 \mathrm{~h}$ postmortem. These results were in lieu with the spectrophotometric activity analysis which showed negligible activity of calpains and calpastatin after $24 \mathrm{~h}$. Similar, results were also reported by Lee, et al. [7] in chicken breast muscle, and according to them, 


\section{Food Science and Nutrition Technology}

predominant band at molecular weight $110 \mathrm{kDa}$ disappeared in between 3 and $6 \mathrm{~h}$ of post-mortem holding whereas the band of $75 \mathrm{kDa}$ decreased after $6 \mathrm{~h}$. Moreover they also stated the presence of $30 \mathrm{kDa}$ band increased after $6 \mathrm{~h}$, indicating the hydrolysis of troponin $\mathrm{T}$ by calpain, which was in lieu with our study. Similar, findings were also reported for goat leg muscles [11].

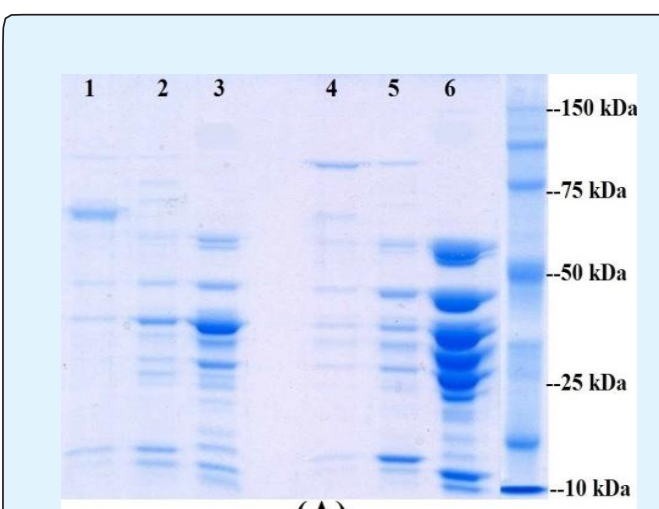

(A)

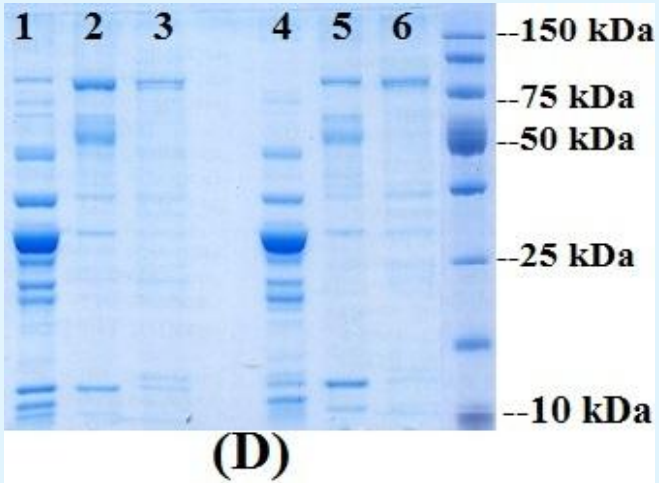

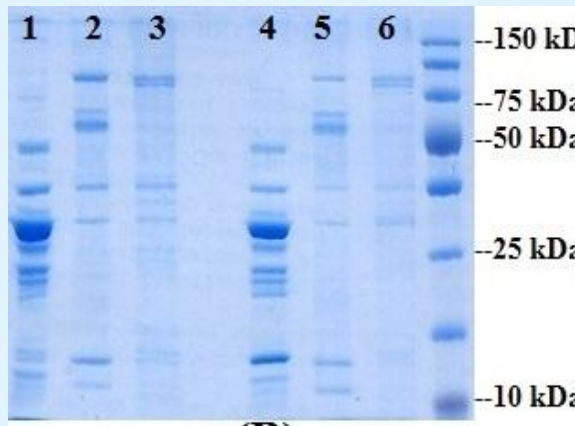

(B)

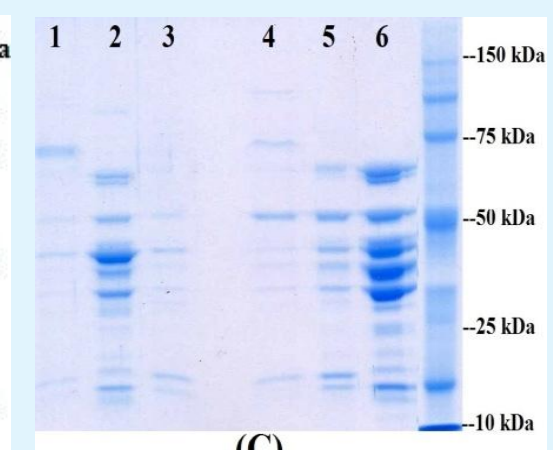

(C)

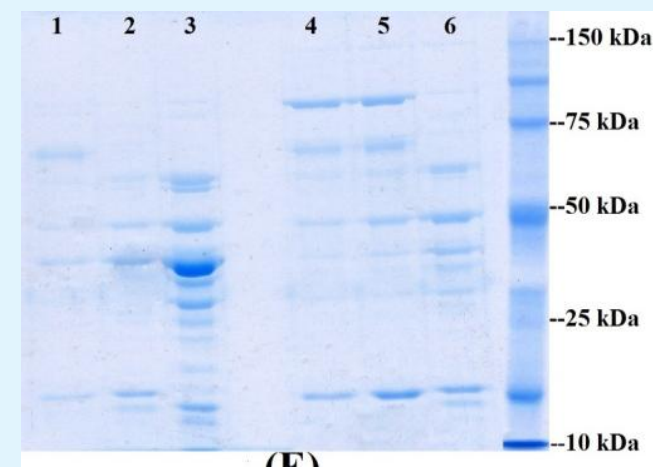

(E)

Figure 2: Calpains and calpastatin on SDS-PAGE gel.

(A) Lane-1: Swetambari blood $\mu$-calpain; Lane-2: Swetambari blood $m$-calpain; Lane-3: Swetambari blood calpastatin; Lane-4: Pearl blood $\mu$-calpain; Lane-5: Pearl blood $m$-calpain; Lane-6: Pearl blood calpastatin.

(B) $0 \mathrm{~h}$ Swetambari: Lane-1: Breast calpastatin; Lane-2: Breast $m$-calpain; Lane-3: Breast $\mu$-calpain; Lane-4: Thigh calpastatin; Lane-5: Thigh $m$-calpain; Lane-3: Thigh $\mu$-calpain.

(C) 24 h Swetambari: Lane-1: Breast $\mu$-calpain; Lane-2: Breast calpastatin; Lane-3: Breast $m$-calpain; Lane-4: Thigh $\mu$ calpain; Lane-5: Thigh $m$-calpain; Lane-3: Thigh calpastatin.

(D) 0 h Pearl: Lane-1: Breast calpastatin; Lane-2: Breast $m$-calpain; Lane-3: Breast $\mu$-calpain; Lane-4: Thigh calpastatin; Lane-5: Thigh $m$-calpain; Lane-3: Thigh $\mu$-calpain.

(E) 24 h Pearl: Lane-1: Thigh $\mu$-calpain; Lane-2: Thigh $m$-calpain; Lane-3: Thigh calpastatin; Lane-4: Breast $\mu$-calpain; Lane-5: Breast $m$-calpain; Lane-3: Breast calpastatin.

\section{Calpains and Calpastatin Activity in Blood and Post-Mortem Muscle}

Casein zymography results clearly indicated that $\mu$ calpain retained its activity upto $6 \mathrm{~h}$ for breast muscle samples and after that it was completely autolyzed, these variations were detected through spectrophotometric activity analysis. It was found that the activity of $\mu$ calpain, m-calpain and calpastatin from blood samples of Swetambari was significantly $(\mathrm{P}<0.05)$ higher than $\mu$ - 


\section{Food Science and Nutrition Technology}

calpain, m-calpain and calpastatin of Pearl. But, it was found that activity of these enzymes was higher for muscle samples in both the varieties. Again the activity of calpains and calpastatin was higher for Swetambari than that of Pearl varieties. However, post-mortem activity analysis of $\mu$-calpain (Table 1) from breast and thigh muscle decreased by 93 and $84 \%$ for Swetambari whereas it decreased by 88 and $80 \%$ for Pearl at $24 \mathrm{~h}$. Post-mortem maturation has very little effect on activity analysis of m-calpain (Table 1) from breast and thigh muscle as it decreased by 4 and $7 \%$ for Swetambari whereas by 3 and $6 \%$ for Pearl at $24 \mathrm{~h}$. Calpastatin activity of breast and thigh muscles also varied slightly during post-mortem maturation and decreased by 13 and $16 \%$ for Swetambari and 11 and $16 \%$ for Pearl at $24 \mathrm{~h}$. Activity analysis results were in comparison with the studies conducted for lamb Longissimus muscle [18], and according to them, proteolytic activity of $\mu$-calpain remained almost unaffected for more than $72 \mathrm{~h}$.

\section{Changes in $\mathrm{pH}$ and $\mathrm{W}$ - $\mathrm{B}$ shear force value (WBSFV)}

It has been observed that the $\mathrm{pH}$ value of breast and thigh muscle samples decreased significantly $(\mathrm{P}<0.05)$ with the increase of post-mortem maturation. However, just after slaughter it was reported that the $\mathrm{pH}$ of breast muscle was higher than that of thigh muscle samples for both the varieties. (Table 2) depicts significant $(\mathrm{P}<0.05)$ decrease in $\mathrm{pH}$ value of breast and thigh muscle up to $6 \mathrm{~h}$ for both the varieties. This significant decrease in $\mathrm{pH}$ is due to the breakdown of glycogen to lactic acid. The $\mathrm{pH}$ value reached at $24 \mathrm{~h}$ post-mortem is termed as ultimate $\mathrm{pH}$ after which $\mathrm{pH}$ did not change significantly and the muscle reaches rigor [7]. Maddock, et al. [20] have also reported that with the increase in post-mortem maturation the $\mathrm{pH}$ value decreased, and due to this, the calpains started to precipitate resulting in their decreased activity.

\begin{tabular}{|c|c|c|c|c|}
\hline \multirow{2}{*}{ Guneafowl } & \multirow{2}{*}{ Muscle type } & \multicolumn{3}{|c|}{ Post-mortem aging time } \\
\hline & & O hr & $6 \mathrm{hr}$ & $24 \mathrm{hr}$ \\
\hline \multicolumn{5}{|c|}{ pH value } \\
\hline \multirow{2}{*}{ Swetambari } & Breast & $6.59 \pm 0.03^{\mathrm{bD}}$ & $6.09 \pm 0.07 \mathrm{aD}$ & $5.98 \pm 0.01^{\mathrm{aA}}$ \\
\hline & Thigh & $6.46 \pm 0.04^{\mathrm{bc}}$ & $5.99 \pm 0.02^{\mathrm{ac}}$ & $5.95 \pm 0.03^{\mathrm{aA}}$ \\
\hline \multirow{2}{*}{ Pearl } & Breast & $6.31 \pm 0.03^{\mathrm{bB}}$ & $5.81 \pm 0.07 \mathrm{aB}$ & $5.89 \pm 0.05^{\mathrm{aA}}$ \\
\hline & Thigh & $6.17 \pm 0.05^{\mathrm{bA}}$ & $5.68 \pm 0.03^{\mathrm{aA}}$ & $5.75 \pm 0.04^{\mathrm{aA}}$ \\
\hline \multicolumn{5}{|c|}{ WBSFV $\left(\mathrm{Kg} / \mathrm{cm}^{2}\right)$} \\
\hline \multirow{2}{*}{ Swetambari } & Breast & $4.62 \pm 0.05^{\mathrm{bD}}$ & $3.96 \pm 0.04 \mathrm{aD}$ & $3.59 \pm 0.05^{\mathrm{aA}}$ \\
\hline & Thigh & $3.81 \pm 0.02^{\mathrm{bB}}$ & $2.98 \pm 0.05^{\mathrm{aB}}$ & $2.57 \pm 0.03^{\mathrm{aA}}$ \\
\hline \multirow{2}{*}{ Pearl } & Breast & $4.23 \pm 0.07 \mathrm{bc}$ & $3.68 \pm 0.04^{\mathrm{ac}}$ & $3.48 \pm 0.06^{\mathrm{aA}}$ \\
\hline & Thigh & $3.56 \pm 0.03^{\mathrm{bA}}$ & $2.65 \pm 0.07 \mathrm{aA}$ & $2.51 \pm 0.02^{\mathrm{aA}}$ \\
\hline
\end{tabular}

Table 2: Changes in $\mathrm{pH}$ and Warner-Bratzler shear force value of during post-mortem maturation at $4 \pm 1{ }^{\circ} \mathrm{C}$. $\mathrm{n}=20$; Mean \pm S.E with different superscript row-wise (small letter) and column-wise (capital letter) differ significantly $(\mathrm{P}<0.05)$.

Warner-Bratzler shear force value was measured to determine the role of $\mu$-calpain mediated post-mortem tenderization on the texture quality of meat. WBSF value for breast and thigh muscles decreased significantly $(\mathrm{P}<0.05)$ during the post-mortem maturation, with breast muscle showing higher value than thigh muscle (Table 2). It has been deduced that Swetambari has higher value of WBSF than Pearl. These variations have significant effect on tenderness of meat. WBSF values were in relation with zymography and activity analysis results, showing the optimum tenderization at $6 \mathrm{~h}$ post-mortem. Moreover these findings were supported by the analysis conducted by Liu, et al. [21] who also stated that meat kept for postmortem maturation showed a significant $(\mathrm{P}<0.05)$ decrease in shear force value with increase in maturation time.

\section{Conclusions}

Proteolytic activity of different enzymes of calpain system in blood and muscle samples was easily identified using casein zymography and SDS-PAGE analysis in two different guinea fowl varieties. Purification and quantification of calpains and calpastatin was performed with high selectivity using Biospectrophotometer. This study paves the way to predict quality of meat by analyzing blood samples just before the day of slaughter. The $\mu$-calpain mediated post-mortem maturation was 


\section{Food Science and Nutrition Technology}

optimized at $6 \mathrm{~h}$ and was found to be on the higher side in Swetambari than in Pearl varieties of guinea fowl birds.

\section{Acknowledgements}

We are thankful to DST, Govt. of India (Grant No. SB/FT/LS-283/2012 Dated- 02.05.2013) for their financial support and ICAR, New Delhi (Ministry of Agriculture and Farmers Welfare) for providing sufficient facilities for sample analysis.

\section{References}

1. Santiago HL, Díaz V, Rodríguez AA (2007) Processing yields, meat quality attributes and nutrient composition of diverging genotypes of guinea fowl (Numida meleagris) broilers reared on various planes of nutrition in a tropical environment. Animal Science 13: $236-238$.

2. Biswas AK, Jairath G, Mandal AB, Khanna S (2015) Non-traditional small poultry species: An approach to food sustainability. Agriculture Review 36: 147-152.

3. Geesink GH Koohmaraie M (1999) Postmortem proteolysis and calpain/calpastatin activity in callipyge and normal lamb biceps femoris during extended postmortem storage. Journal of Animal Science 77: 1490-1501.

4. Huang M, Huang F, Ma H, Xu X, Zhou G (2012) Preliminary study on the effect of caspase- 6 and calpain inhibitors on postmortem proteolysis of myofibrillar proteins in chicken breast muscle. Meat Science 90: 536-542.

5. Koohmaraie M, Seidemann SC, Schollmeyer JE, Dutson TR, Crouse JD (1987) Effect of post-mortem storage on $\mathrm{Ca}^{2 \pm}$ dependent proteases, their inhibitor and myofibril fragmentation. Meat Science 19: 187-196.

6. Kretchmar DH, Hathaway MR, Epley RJ, Dayton WR (1990) Alterations in postmortem degradation of myofibrillar proteins in muscle of lambs fed a betaadrenergic agonist. Journal of Animal Science 68: 1760-1772.

7. Lee HL, Santé-Lhoutellier V, Vigouroux S, Briand Y, Briand M (2008) Role of calpains in post-mortem proteolysis in chicken muscle. Poultry Science 87: 2126-2132.
8. Koohmaraie M (1996) Biochemical factors regulating the toughening and tenderization processes of meat. Meat Science 43: 193-201.

9. Bernard C, Cassar-Malek I, Cunff ML, Dubroeucq H, Renand G, et al. (2007) New indicators of beef sensory quality revealed by expression of specific genes. Journal of Agricultural Food Chemistry 55: 5229-5237.

10. Raser KJ, Posner A, Wang KK (1995) Casein zymography: a method to study mu-calpain, mcalpain, and their inhibitory agents. Archive of Biochemistry and Biophysics 319: 211-216.

11. Biswas AK, Tandon S, Beura CK (2016) Identification of different domains of calpain and calpastatin from chicken blood and their role in post-mortem aging of meat during holding at refrigeration temperatures. Food Chemistry 200: 315-321.

12. Camou JP, Mares SW, Marchello JA, Vazquez R, Taylor $M$, et al. (2007) Isolation and characterization of $\mu$ calpain, m-calpain, and calpastatin from postmortem muscle. I. Initial steps. Jounrnal of Animal Science 85: 3400-3414.

13. Laemmli UK (1970) Cleavage of structural proteins during the assembly of the head of bacteriophage T4. Nature 227: 680-685.

14. Koohmaraie M (1990) Quantification of Ca2+dependent protease activities by hydrophobic and ion-exchange chromatography. Journal of Animal Science 68: 659-665.

15. Salem M, Kenney PB, Killefer J, Nath J (2004) Isolation and characterization of calpains from rainbow trout muscle and their role in texture development. Journal of Muscle Foods 15: 245-255.

16. Trout ES, Hunt MC, Johson DE, Clans JR, Castner CL, et al. (1992) Characteristics of low fat ground beef containing texture modifying ingredients. Journal of Food Science 57: 19-24.

17. Snedecor GW, Cochran WG (1994) Statistical Methods. Oxford and IBH Publishing Co. New Delhi.

18. Veiseth E, Shackelford SD, Wheeler TL, Koohmaraie M (2001) Effect of postmortem storage on $\mu$-calpain and $\mathrm{m}$-calpain in ovine skeletal muscle. Journal of Animal Science 79: 1502-1508. 


\section{Food Science and Nutrition Technology}

19. Geesink GH, Nonneman D, Koohmaraie M (1998) An improved purification protocol for heart and skeletal muscle calpastatin reveals two isoforms resulting from alternative splicing. Archives of Biochemistry and Biophysics 356: 19-24.

20. Maddock KR, Huff-Lonergan EJ, Lonergan SM (2005) The Effect of $\mathrm{pH}$ on $\mu$-calpain Activity and
Implications in Meat Tenderness. Animal Industry Report, AS 651, ASL R1988.

21. Liu Y, Lyon BG, Windham WR, Lyon CE, Savage EM (2004) Principal component analysis of physical, color, and sensory characteristics of chicken breasts deboned at two, four, six, and twenty-four hours postmortem. Poultry Science 83: 101-108. 